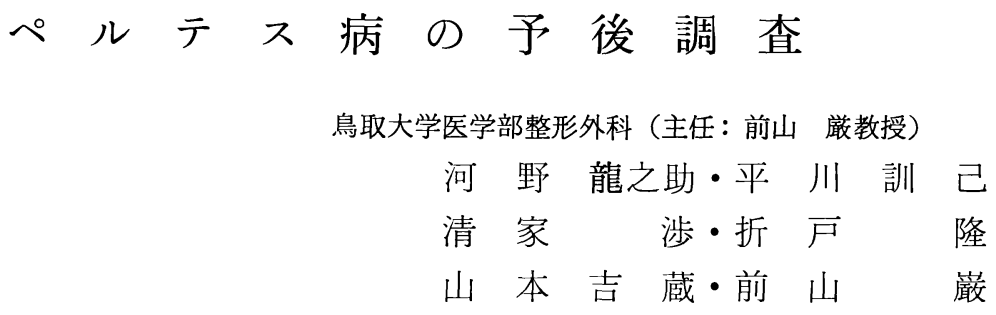

\title{
Follow-up Study of Perthes' Disease
}

by

\author{
R. Kouno, K. Hirakawa, W. Seike, T. Orito, \\ K. Yamamoto and I. Maeyama \\ Department of Orthopedic Surgery, Tottori \\ University School of Medicine
}

\begin{abstract}
The results of operative procedures for Perthes' disease (14 cases of curratage-bone graft, 18 cases of cross-bone graft to the femoral neck and 11 cases of capsulotomy) were studied clinically and roentgenologically.

In curratage-bone graft, ten out of 14 cases showed coxa planomagna and shortening of the femoral neck.

Cross-bone graft had satisfactory results in all cases under 6 year old, but flattened and subdislocated cases over 6 year old had unsatisfactory results.

Capsulotomy was foilowed absorption of the necrotic bone in early time and seemed one of the effective procedures.
\end{abstract}

はじめに

ペルテス病の予後を左右する因子として発症年令, 骨頭傷害の範囲, 近位大腿骨々端線の変化, 大腿骨頸 部の 萎縮や囊包形成など多くの要素が考えられてい る.

今回, 昭和 28 年以降当教室で 施行された 各種の治 療法の結果を比較検討するとともに，予後調査をする 機会を得たのでその結果を報告する.

\section{調査対象および調査方法}

対象は骨頭搔爬骨移植術 14 関節, 頸部十字型骨移 植術 18 関節, 関節包切開術 11 関節で, 各々を $\mathrm{A}$ 群, $\mathrm{B}$ 群およびC 群とする. 各群の平均追跡期間は 17.3 年, 12.5 年, 8.3 年である.

調查方法は臨床像の評価を日整会変股症判定基準に 従って行ない，またエックス線学的評価を Heyman 法および股関節の解剖学的形態より判定を行なった.
骨頭傷害は Catterall の分類に従ったが，骨頭搔爬 骨移植術群では大腿骨々頭への外科的侵襲を考慮して 分類は行なわなかった。

\section{術式と適応について}

A．骨頭择爬骨移植術 Steele 変法として骨頭およ び頸部を開空し，搔爬後腸骨より採取した海綿骨を移 植するととにより骨頭変形の回復と栄養血管の導入を 図ったが，特に症例を限定せず適応とした。

B．頸部十字型骨移植術 西尾により考案され，大 腿骨頸部および骨頭の横径増加を防止し，また頸部に みられる骨壊死や骨萎縮を骨移植によって回復させる 目的で 頸部メタフィーゼに十字型に脛骨片を移植し た. 骨頭陰影の著明な例や頸部に異常を認めるものを 主として適応とした。

C. 関節包切開術 頸部被膜での牽引力の減少を企 図し，関節包切開により，関節外からの副枝血行によ る血流の再開を期待した（西尾）．適応としては骨頭 


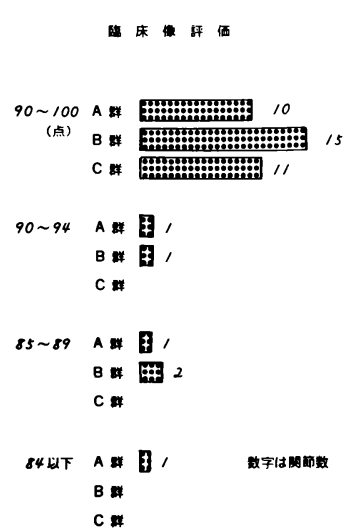

A

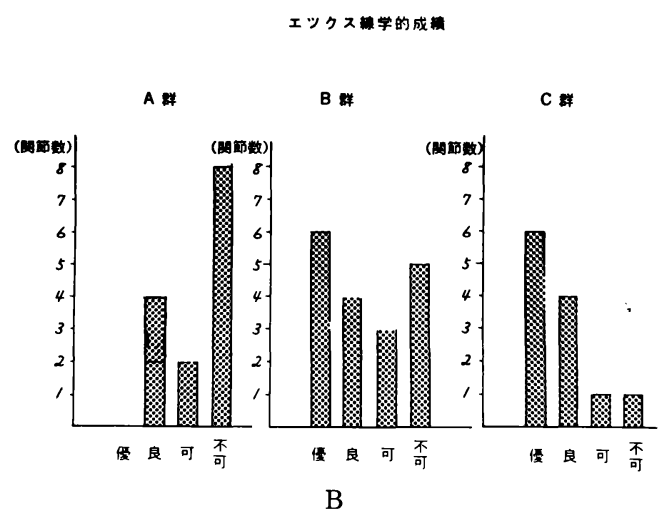

図 1
傷害の軽度な初期例に行なった.

結果

I . 臨床像の評価

各群とも 90 点以上が多く, 特にC 群は全例 90 点以 上を示した. $\mathrm{A}$ 群の成績が一番劣り, 疼痛のあるもの 3 例, 跛行をていするあの 2 例で, 平均 94.8 点であ る. 日常生活動作ではあぐらに支障をきたすすのが 3 例にみられた. B 群では疼痛のあるあのが 3 例で評価 点数は平均 97.8 点であった（図 $1-\mathrm{A}$ ).

II. エックス線学的評価

A 群では優がなく良が 4 関節で残る 10 関節 は可ま たは不可を示している. B 群は優・良例が約半数を占 め, C 群は 2 例を除き優または良となっている（図 1 一B). これらの成績と発症年令, 病期および骨頭傷 害についてエックス線学的に検討した.

1）発症年令と成績

$\mathrm{A}$ 群では発症年令と関係なく, 扁平・過大骨頭が多 く, 可または不可が多い. B 群では 6 才以下の症例に 優・良例が半数を占め, 高年令になるにつれ可・不可 例が増えている. C 群はB 群と同様に6才以下の若い 年令において良好な成績を示している（図 $2-\mathrm{A}$ ).

2）骨頭傷害之成績

骨頭傷害の分類は Catterall に従いB群およびC 群について検討すると両群とも Group I， II におい て成績は優れている. Group III, IV では成績は不良 となっている(図 2-B).

B 群およびC 群において発症年令ならびに骨頭傷害 と成績の関係をみると年令が低く, また骨頭傷害の軽
いもの程成績は良好となっている（図 3 ）。

3）病期と成績

病期は片山の分類に準じて初期，中期および後期に 分け検討すると, A 群は中期と後期例が比較的多くを 占め, 骨頭変形を残し成績は不良である. B 群とC 群 では初期例において良好な成績を示しているが，中期 および後期例では成績は悪くなっている（図 $2-\mathrm{C}$ ).

4) 術後エックス線学的経過

骨頭修復の完了した時点でェックス線学上軽度の変 形を残しても，成長を通じて変形の増強も考えられる ので, 経時的変化を Heyman 法によって検討を加え た.

$\mathrm{E} \mathrm{Q}$ 值はA 群では $80 \%$ 以下が全例で骨頭の圧平が 持続していることを示し，B群では $80 \%$ 越えるす のが約半数認められ，C群は殆んど $80 \%$ を越えてい る(図 $4-\mathrm{A}$ ).

$\mathrm{HNQ}$ 值では C 群が良好で $\mathrm{A}$ 群および $\mathrm{B}$ 群は術後経 年的に下降し, 頸部の短縮の進行を示している（図 4 - B ).

AHQ 值は全群とも $80 \%$ 前後している. 術後骨 頭の巨大化の進行は著明でないことを示している（図 $4-\mathrm{C}$ ).

考察

骨頭搔爬骨移植術は搔爬後骨頭へ骨移植をすること により骨頭の圧平の回復と血行改善を図ったが, 術後 骨頭の圧平は進行している例が大部分であった. てれ らの症例の近位大腿骨々端線をみると, 骨頭外側にお いて早期の骨端線閉鎖がみられ，その結果骨頭は外側 

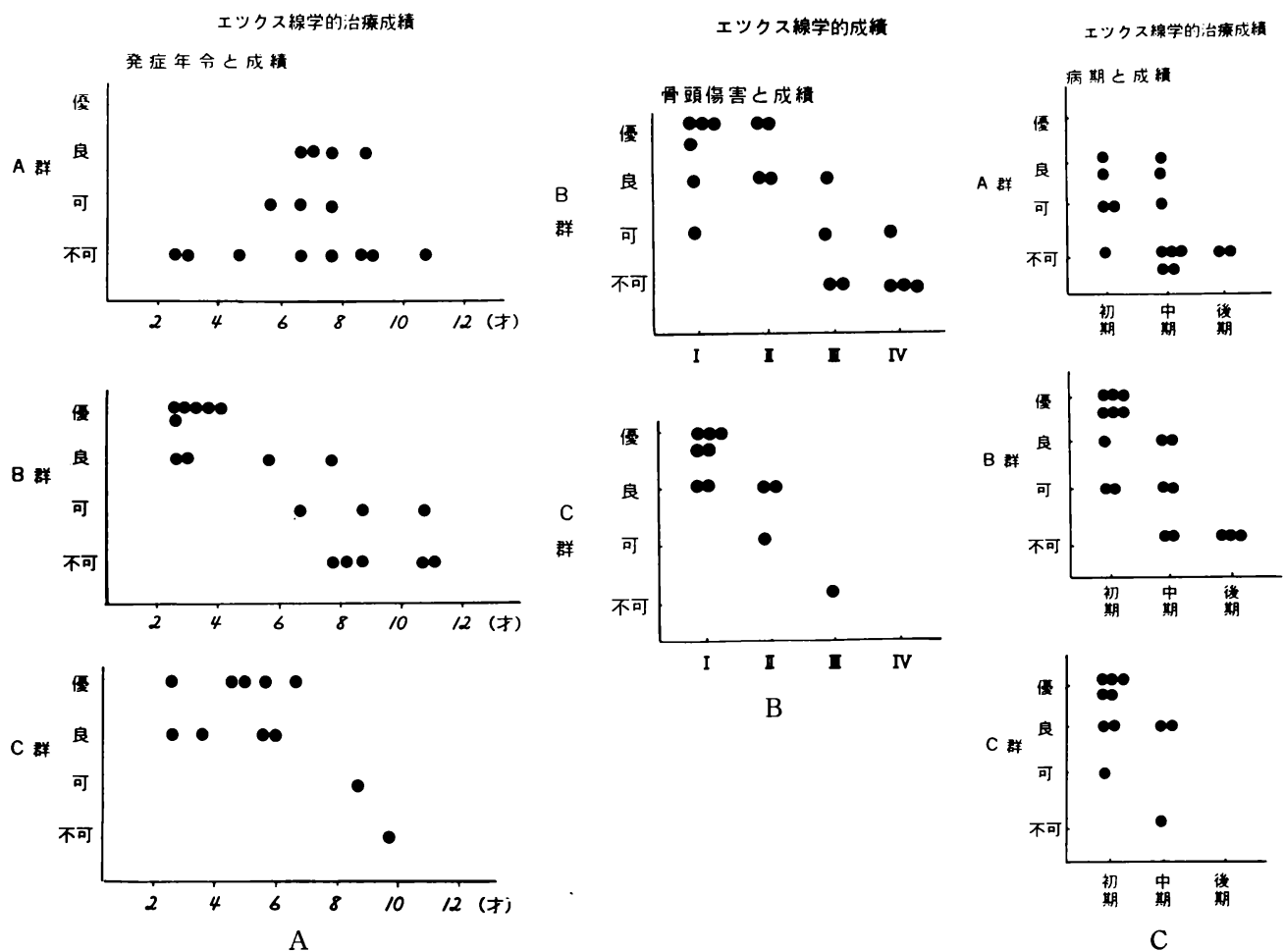

図 2

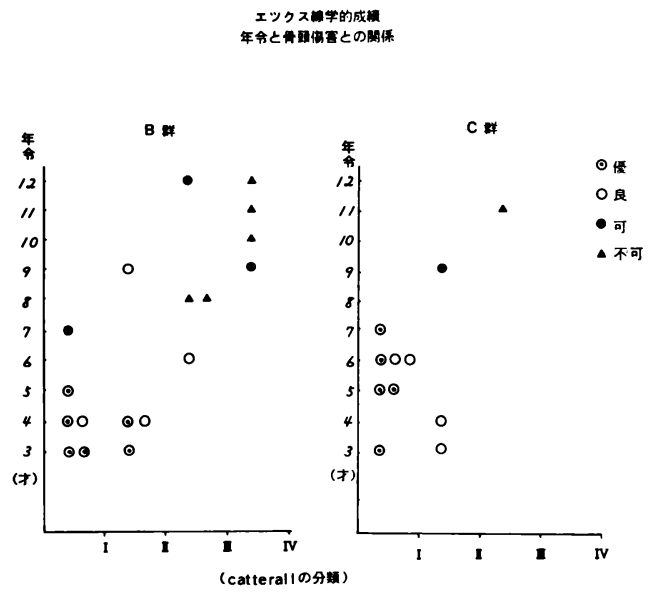

図3

が厚く内側が低い骨端を示している．乙れが成長とと あに著明となり，扁平骨頭へと移行している（図 $5-$ 4 ).

頸部十字型骨移植術は骨頭と頸部部の横径増加およ び頸部の短縮の防止という手術目的は完全には達し得
なかった. しかし 6 才以下の症例で頸部の変化の少な い症例では成績は良好であった（図 $5-B$ ). また 6 才以上で骨頭の濃厚陰影の著明な例や頸部に萎縮など の変化のある例では過大骨頭や頸部短縮がみられた. しかし骨頭は比較的円形を保っていた. 本手術施行例 のうち可および不可を示した症例は 7 才以降の年令 で，骨頭の 圧平が高度で 亜脱臼を有するものであっ た.

本手術の術後経過から骨移植の効果とは考えられな い骨頭変化が早期にみられた，骨頭の雲恕状変化や骨 頭壊死部の早期の吸収や淡影化である. これらの変化 は関節包切開による効果と考え, 頸部被膜での栄養血 管の侵入部での除圧が主因と思われた. 以上の考えの あとに旋行された関節包切開術施行例の成績は 2 例を 除き優または良を示した. 6 才以上で Group 3 の 中 期の症例（2 例）に本法を施行したが予後は不良であ った. 本法の適応は初期例が有効と考えられる（図 5 -C).

今回の予後調査ではエックス線像で股関節に変形を 認めるにあかかわらず臨床像の評価では 90 点以上が 
EQD相 13
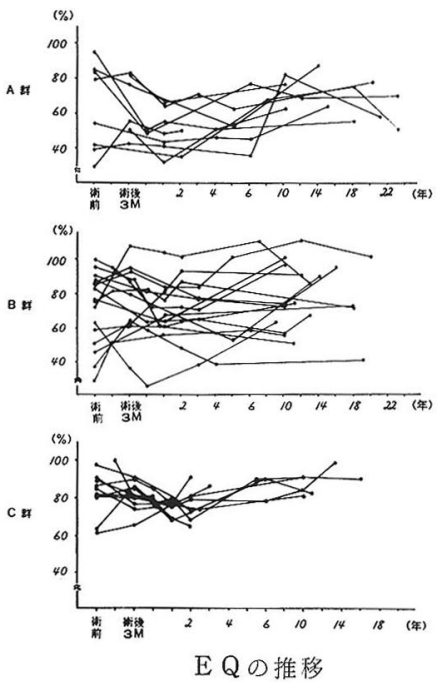

A
HNQ⿻ 数 13
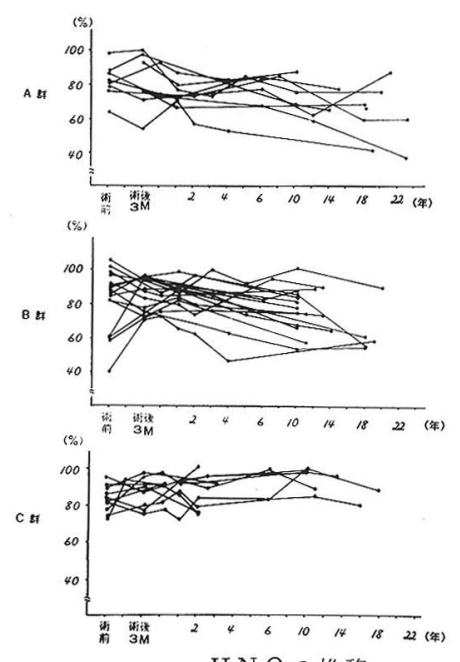

$\mathrm{HNQ}$ の推移

B
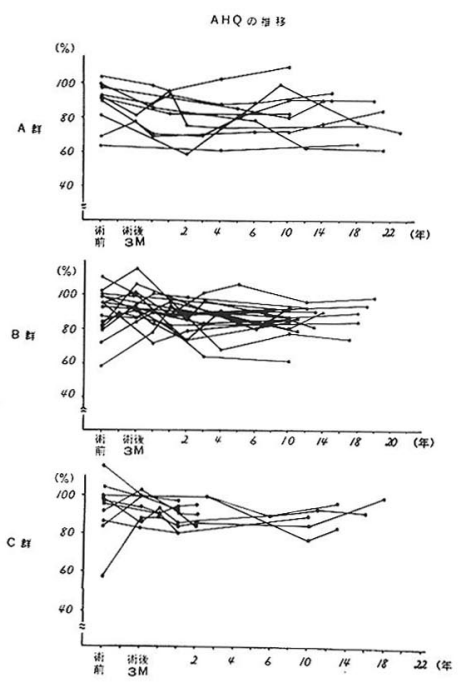

A N Q の推移

C

図 4

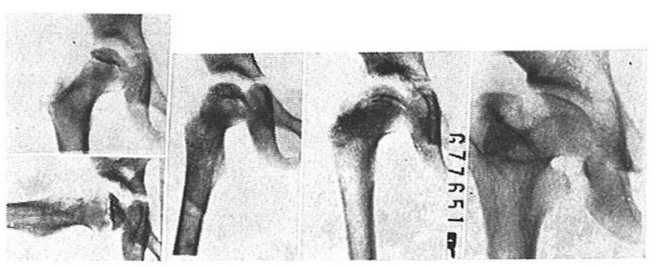

術前術後 1 力月 術後 3 年

A 骨頭掻爬骨移植術6才

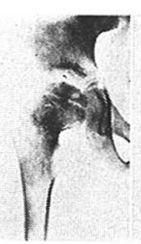

術 前 術後 3 万月 術後10年

B 项部十字型骨移植尃

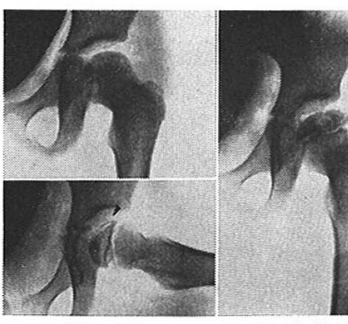

術前術後 9 力月

C 関節包切開術 5 才 傮

図 5
大多数で 90 点以下は 4 例にすぎない，疼痛のあるす のは6例にみられたが軽度でかつ不定期であり，日常 生活に殆んよ゙支障をきたしていない。

各群を通じて術後 10 年以上経過した 36 関節中エッ クス線学的に過大骨頭や頸部短縮などの変形 (可・不 可例の 22 関節) を有してあ変形性股関節症の 所見が みられるのは 4関節化過ぎなかった. Ratliff や Gower の長期追跡結果は変形はあっても年令や追跡期 間の增加と共に症状の進行はないととを示している. 小野らの 10 年以上の追跡では 36 例中 6 例に変形性股 関節症への移行を述べている.とのととはペルテス病 での股関節症の発生頻度は低いと考えられるが，一方 Danielson の報告では高度の 変形例では変形性股関 節症になりやすく，また年月ととあに進行するとい う.われわれの調查では不定期の疼痛や跛行を有する 変形例（6例）では過大・扁平骨頭飞対し関節裂隙は 広く保たれているが，臼蓋前面は水平または波状で小 さく将来股関節症の発生が心配される.

\section{ま と め}

1. ペルテス病に対して行なった骨頭搔爬骨移植術 (14 関節)，頸部十字型骨移植術（18 関節）および関 節包切開術 (11 関節) について予後調査を試み, そ の成績を比較検討した. 
2. 全例を通じて臨床像の評価は良好で 90 点以下 のものは 4 例にすぎなかった.

3. 骨頭搔爬骨移植術施行例では扁平骨頭や頸部短 縮がみられ，その成績は可および不可が多くを占め た.

4. 頸部十字型骨移植術施行例では 6 才以下の症例 で成績は良く，また骨頭の高度圧平や亜脱臼を有する 6 才以上の症例で成績は悪く, 頸部短縮や過大骨頭を 示すむのが多かった.

5. 関節包切開術施行例では術後骨頭の淡影化や吸 収が早期にみられ, 初期例に対し有効な治療手段の一 つと考えられた.

6. 全群を通じてエックス線学上変形性股関節症の 所見を認めたのは 4 関節に過ぎなかったが，扁平過大 骨頭を有する症例では将来変形性関節症の発生が予想 された.

\section{参考 献}

1) Catterall, A.: The natural History of Perthes Disease. J. Bone and Joint Surg., 53-B: 37-53, 1971.

2) Danielsson L. G. et al.: Late Results of Perthes Disease. Acta Orthop. Scandinav., 36: 70-81, 1965.

3) Gower W. E. et al.: Legg-Perthes Disease. J. Bone and Joint Surg., 53-A: 759$768,1971$.

4) Heyman, C. H. et al.: Legg-Perthes Disease. A Method for Measurement of Roentgenographic Results. J. Bone and Joint Surg., 32-A : 767-778, 1950.

5) 片山良亮: 片山整形外科学, 中外医学社, 748 , 1970.

6）西尾篤人・他：ペルテス氏病の骨頭择爬骨移植 術. 日整会誌, 31：382-383, 1957.
7）西尾篤人・他：ペルテス病とその外科. 外科治 療, 4: 490-509, 1961.

8）西尾篤人・他：ペルテス病の治療法の検討。日 整会誌, 38:525-526, 1964.

9)西尾篤人：ペルテス病の治療法, 整形外科, 20: 177-180, 1969.

10）小野勝雄・他：10年以上経過したペルテス病の 予後とその検討。臨整外，10:389-396, 1975.

11) Ratliff, A. H. C. : Perthes Disease. A Study of Thirtyfour Hips Observed for Thirty Years. J. Bone and Joint Surg., 49B: 102-107, 1967.

\section{質 問 長崎大整形 岩崎 勝郎}

骨頭搔爬骨移植術, 頸部十字型骨移植術および関節 包節開術などがペルテス病の natural history に影 響を及ぼすと考えられるか.

\section{解 答鳥取大整形 河野竜之助}

術後早期に骨頭壊死部の吸収や炎影化がみられる点 において natural history と相違していると考えら れる.

\section{質 問琉球大整形 茨木 邦夫}

ペルテス病の治療としての derotation-varus osteotomy を行なっていますか.

行なっているなら，その他の治療との差はどうです か.

\section{解 答鳥取大整形 河野竜之助}

6才以上の症例で，骨頭壊死部の改善がみられない 場合や，亜脱臼を示す場合，内反骨切り術あるいは骨 盤骨切り術（chiari）を最近は行なっている. 